\title{
New Year's Day in Scotland, 1909
}

\section{David Rorie}

To cite this article: David Rorie (1909) New Year's Day in Scotland, 1909, Folklore, 20:4, 481-482, DOI: 10.1080/0015587X.1909.9719902

To link to this article: http://dx.doi.org/10.1080/0015587X.1909.9719902

$$
\text { 曲 Published online: } 14 \text { Feb } 2012 .
$$

5 Submit your article to this journal $₫$

$$
\text { Цll Article views: } 1
$$

Q View related articles $\sqsubset$ 


\section{COLLECTANEA.}

New YkaR's Day in Scotrand, Igog.

The following notes were compiled from the local paragraphs in the Aberdeen Free Press and The Scotsman for Jan. and, Igog.

Games.:

Dornoch.-The all but obsolete game of "bools" was engaged in on the links by about 50 people.

Kirkcaldy.-Ravenscraig Castle was, as usual, thrown open to the public for the day, and the ancient game of "Bawbee she Kyles" was taken part in.

Kirkwall.-The chief form of amusement was the ball playing. $\because$ The ball for boys fell to the Down-the-gates; that for youths to the Up-the-gates. The struggle for the men's ball was a most determined one, and ... ultimately the Up-the-gates were victorious. (Cf. Gomme, The Traditional Games of England, etc., vol. i., pp. 135-7.)

Wemyss, -The "Kyles," a game peculiar to Wemyss, was Played yesterday, when the medal was won by Thos. Coventry, W. Wyles, a former winner, being runner up. [This game is played with a metal ball and leather thong.] ${ }^{2}$

\section{Guizing or Mumming.}

Kelso.-Bands of youngsters were out "guizanting." (Guizan. ting is synonymous with guizing. A long account of "The Dying Guizard," or guizer, appeared in The Scotsman, Dec. 31st, x902.)

'Further information as to the games is desired. They are not described in Mrs. Gomme's Traditional Games except where indicated.-Ev.

"Is this similar to the game described in "More Notes on Old English Games," Badminton Magasine, Jan. 1897, as Kailles or Cayles, played with hine shank bones of cattle and a stick or wooden bowl to throw at them? 
Lerwick.-As on Christmas Eve, a large number of "guizers," young and old, were in evidence. The custom of going "guizing" is decidedly on the increase in Lerwick, and the fun and frolic are entered into largely by young and old.

North Bertrick. - "Guizing" amongst the younger portion of the community was largely in evidence on Hogmanay night.

\section{Other Practices.}

Auchterarder.-Huge bonfires were kindled at the Townhesd and the Common Loan.

Banff brought in the New Year with a pipe and drum band and the firing of squibs, rockets, etc.

Berwick, Earlston, Inverleithen, Kelso, and Kirkcudbright mention "firstfooting" as being on the wane, while Haddington" Hawick, and Kilmarnock mention a good deal of it.

Earlston. - The territorials, following the example of their pre" decessors, had the annual wapinschaw on the range at the Blacks Hill.

Fordyce.-Scarcely had the chimes of the Old Year died away when the village youths were busy at the time-honoured custom of removing the mortar-stone ${ }^{8}$ to the door of the young lady whom they wish to see joined in wedlock during the year.

Keith. -The Institute Bell was tolled for half an hour, and the engine-drivers at the station kept their engine whistles going for a like period.

DAvid RORII.

s Particulars are desired. - ED.

\section{INDIAN FOLKLORE NOTES, II. ${ }^{1}$}

I AM again indebted to the courtesy of one of our members, Mit Halliday Sparling, for numerous cuttings from current Indian newspapers, from which I give some extracts :

Sympathetic magic; sacrificing an animal to cause injury to an enemy. - In South India the head of a fowl which has dark.

"For I. see "Some Notes on Indian Folklore," ante, pp. 21 -3.3. 